\title{
6. STRATEGIES FOR MODELLING THE EDUCATIONAL PROCESS FROM THE PERSPECTIVE OF INTERNAL RESOURCES STIMULATION OF THE CHILD
}

\author{
Elena Zolotariov ${ }^{109}$ \\ Eugenia Foca ${ }^{110}$
}

\begin{abstract}
The article reflects an attempt to rethink the methodology of organizing the pedagogical process, oriented towards the development of "the humane in the person ", shifting its focus onto stimulating children's inner resources. The emphasis is shifted from the teaching, learning and assessment processes, focused on research of the surrounding reality towards the exploitation of the child's innate potentials, the ability to know his inner world.

Maintaining the innate resources of each learner will require from teacher of post-modern school the application of techniques to create the necessary social and psychological conditions, to provide a path for learners' individual development. Thus, each child will have the chance to realize their potential talent, including sensitive dimension of their spiritual and moral world, this representing the authors' research subject.
\end{abstract}

Key words: child, emotional intelligence, spiritual intelligence, moral reasoning, artpedagogical strategies

\section{Introduction}

In today's society when life accelerates the pace, we are forced to comply with the outside world rather than focus on our inner world. This is due to the lack of ability to solve problems, to make choices based on a conscious effort to reasonably analyze the consequences of the possible outcomes of potential decisions. Such a conscious choice involves the inner dialogue, which requires guidance on how to develop in the spirit of true morality. The contribution of education to the consolidation and maintenance of this dialogue is an imperative, thus offering the human individual the ability to make moral decisions independently, using one's own inner voice.

Unfortunately, the development of technologies exceeded the moral development and the "common sense", achieved by the society. In this process, we lost the natural order of priorities, commitment to values, our collective dignity and respect, independence and, finally, we lost the freedom to exercise our will without fear or uncertainty (Methus, 2013). Therefore, reviewing the quality of education, especially the stimulation of human spirituality and morality, should become an imperative. The issue is not just to prepare the children for the integration into the society, but also to create them the opportunity to understand the surrounding world and to have a responsible and correct behavior (Delors, 2000). It is essential for education to allow people the

\footnotetext{
109 Associate Professor PhD., „Alecu Russo” State University from Bălţi, Republic of Moldavia, email: focaeugenia@mail.ru

${ }^{110}$ Lecturer, Doctoral Candidate, „Alecu Russo” State University from Bălţi, Republic of Moldavia, e-mail focaeugenia@mail.ru
} 
freedom to think and judge, to feel and create, to ensure that they develop their talent and remain as long as possible at the helm of their lives.

Our study revolves around the didactics of moral generalizations and developing the awareness of moral value of an action, based on the benchmarks of universal ideal, highlighting a number of important elements. They seek to offer competent support to the young humans in discovering their neighbor and themselves through the emotional anticipation of consequences of the facts that influence the inner state, from early childhood (Zolotariov, 2014). Traditional pedagogy, as we have seen, is not particularly concerned with the formation of full value representations about the quality of moral behavior, children's abilities to interpret the moral sense of actions in line with the essential characteristics of the social ideal set up. According to the authors of philosophical and psychological works, this standard foreshadows the idea that "moral actions do not involve achieving some pragmatic goals by the subject, but are oriented, in the first place, towards the scope of interest of another person", implying "harmonization and balance with other people's interests", the rewards and benefits being "in the conscience of the individual " (Zolotariov, 2014, pp. 2021).

\section{Discussions}

The concept provides that to be happy, we need to know how and to be willing to make happy as many people as possible. Hence, the mission of education is to organically lead the disciples to awareness of moral value of actions and to teach them take decisions, oriented to another person, independently, referring to the essential characteristics of the social model. Awareness of moral value of one's actions can have a stimulating and regulating effect on the implementation of human morals in a problem or conflict situation. As noted in this respect by S. Rubinstein, the awareness that something is good (debt) has a moral content, sufficient to determine the need to make specifically this thing. It is not the attraction in its specific meaning of the word, but a driving force, however, sufficient to generate a behavior contrary to the attraction (Abulihanova-Slaveanskaia, 1979; Asmolov, 1989).

Developing S. Rubinstein's idea, other authors show that proper moral understanding and evaluation of possible alternatives to a certain behavior should be among cognitive prerequisites, necessary for a child to become a subject of moral self-control, while personality prerequisites include discontent with oneself, in case of violation of moral norms (Iacobson, 1984). This view is consistent with the opinion, shared by the supporters of cognitive development theory, who believe that a moral action must be intermediated by purely moral judgments and views, taking into consideration the universal moral criteria in line with the conscious moral values of the individual. The results of the studies, analyzed in A. Blasi's work (Blasi, 1980) generally support this idea.

The above-mentioned information reveals the need to alter the approach to the educational process. Namely, the issue lies in identifying the pedagogical tools to help the learners track their moral development progress so that the 
reward of achieving a goal, related to those around the learners be the "satisfaction with the type of behavior that is in line with their own code of ethics" (Methus, 2013, p. 68). We shall further refer to some of the changes that provide the teacher guaranteed solutions to achieve this result.

(1) The main idea is the philosophical perception of the child that identifies his innate capital, which could be a support in the pedagogical activity. Referring to the spiritual potential, scientists emphasize the child's capacity to love his parents (not for something specific, but unconditionally, without asking for anything in return, to believe sincerely in them, tending to their selfdetermination, often contrary to the effort of the adults surrounding him, including teachers). This spiritual resource of sensorial-cognition energy is the power of every child, while the adult's role is to help the child preserve and strengthen it, rather than to deform it through a distorted representation of the world and of the child's place in it.

Moreover, the innate spiritual potential of the child to manifest his love for the neighbor is gradually exhausted, when these resources are not accepted or are neglected. Therefore, it is undeniable that parents and teachers need competent support to understand and be able to create favorable conditions for the preservation and realization of spiritual and intellectual forces of child's vital activity (Anisimov, 2014). Based on the above-mentioned information on the innate spiritual potential of the child, we can understand the meaning of these individual forces, as well as the semantic, value, spiritual and intellectual components, which will have to be emphasized in a special pedagogical process.

We will keep in mind that the child is born with fundamental needs for Love, Faith and Predestination, along with the so-called spiritual or psychological needs, such as the emotional and intellectual potential in the process of self-cognition and learning about his place in life and having "creative potential to implement them in the structure of moral relations" (Anisimov, 2014, p. 275). The child is a phenomenon that carries out his vital mission and is endowed with the highest power of the Spirit. Such a faith in the child will allow the teacher to interact with learners in the educational process on an equal basis, will inspire optimism, and will form the child, based on the principles of creativity, which will contribute to the confirmation of the personality development, for which the teacher is responsible.

This context generated the idea about the need to use the possibilities and conditions of the child's initiative activities to ensure his orientation towards universal moral values. According to the cultural-historical conception of the psychologist L. Vygotsky, only through this activity the child can develop personality traits, through which a growing personality could make an independent judgment to meet the moral and ethical requirements, established by the society (Zolotariov, 2014). Instability of traditional pedagogy in this respect appears to be driven by the implementation of the normative and ethical principles approach, according to which the formation of personality's moral conscience is seen as a direct and immediate result of educational and instructional impact, coming from outside. In these conditions, we notice 
discrepancies between the "verbal" and "real" levels in the development of norms and rules of human relationships. Development of psychological mechanisms that are most likely to provide moral guidance for behavioral actions remains outside the pedagogical concerns.

Hence, we face the major problem of the contemporary educational system: the incompetence of the majority of teachers to master, except the didactic aspect of a discipline, the system of productive and reflexive techniques that allow them to create a constructive environment for the learners' development throughout the educational process that will enable them to understand the sorrows and joys as tonalities of their soul, to know themselves, discovering and enriching their creative potential on the arduous path of spiritual development.

Currently, the teacher-practitioner has to act intuitively (almost "blindly") while building the management process of a child's self-cognition in the existing environment, being unable to create suitable conditions for the child to explore his inner world. Indeed, the current educational system has no discipline, directed towards the child's self-cognition and manifestation of his inner world, because all the disciplines are directed towards the study of the surrounding world. The experts are wondering if it is not the reason why all educational systems in the world are going through a crisis (Anisimov, 2014). Alternatively, Constantin Cucoș claims that the youth today are tormented by a larger number of questions like, "Why should we adorn the spirit or our inner world, if visible competences, professional skills, our exterior and the façade are demanded to a greater extent? Why should we be interested in what a person "is", what is "inside" this person, what s/he "thinks", or what s/he can "become"?" (Cucoș, 2008).

We witness today that education focuses on knowledge, so that the child is "swallowed" by the system that ignores, for example, the free and enjoyable art activities. In these circumstances, there is a need to find a common field of actions of autonomous subjects, such as pedagogy, psychology and art, where the "harmony, or the mental and physical balance of life comes only from and through art" (Șușală, 2000). This creates a new concept, that of "art pedagogy", that gains more and more followers and is currently a priority for researchers in science of education. We can depict various approaches to the concept of artpedagogy, applied to certain dimensions and its impact on different categories of educational subjects in the researches, conducted by Russian authors. For instance, Taranova (2003) - moral education of preschool children by applying art-pedagogy, Guzeeva (2004) - professional training of future psychologists for patriotic education of students through art-pedagogy, Shumakova (2006) - artpedagogy as a system to humanize students in the field of physical education, Valeeva (2007) - socializing of adolescents through art-pedagogy strategies, specific for non-formal education, Smetanina (2008) - the use of art-pedagogy to ensure spiritual and moral development of students in complementary education, Anisimov (2009) - art and morality: conceptualization of the object of study of art-pedagogy, Sergeeva (2010) - influence of art-pedagogy on the 
professional training of future teachers, Catrenko (2011) - art-pedagogy as a creative technique for students in physical education (Foca, 2015, p.302).

Representatives of art-pedagogy suggest that in the case of self-control, which is the result of a special training, of the possibility to examine oneself and one's actions in the context of inner dialogue, the child will become able to express his constructive potential to manifest himself socially an psychologically in the search for meaning of his existence. Moreover, there occurs a distortion of the true development trajectory and the innate spiritual energy resources are exhausted in the course of human maturation process (Anisimov, 2003).

Art-pedagogy strategies aim to activate creative resources, existing in the child to overcome the difficulties of school life, directing the child to concentrate on himself, develop communication and interacting skills. It should be emphasized that working strategies of our study are taken from the fields of plastic art, music, dance, movement, drama, etc., but not in order to produce art, or to acquire creative skills, but to live aesthetic emotions that along with the cognitive and moral ones, can help overcome various problems in school and everyday life. It is vital, therefore, that such a vision inspire and govern the education, both in terms of content and methods of intervention. Promotion of spiritual and moral values, harmonized with universal ideal criteria for judgment and actions, as an alternative strategy to overcome the current crisis of the educational system can and should become a constant concern to school in the broad sense of the word.

(2) We need a specific purpose in order to reorient education towards the spiritual and moral dominant. According to the experts in the field, the central task of education in today's conditions is to remove the man from the objective material world, which in fact, has already exhausted its reserves, by focusing on the "kingdom of the spirit", where one can find one's true values and where the supreme Ego will exist in order to reveal and realize oneself. From this perspective, the study that we conducted comprises a system of formative educational activities, aimed at promoting and fostering emotional intelligence (Goleman, 2008) and spiritual intelligence (Torralba, 2012) in every child. The idea is to create favorable conditions that allow learners a high level of functionality and competitiveness, by focusing on the principles of liberty, followed in their turn, by a high level of morality and responsibility. Saturation of the formative educational process with sublime and subtle pictures that feed the soul and heart of a child to mature and become free turned out to be an effective tool to achieve this result (Zolotariov, 2014).

These images-values serve as spiritual ferments. These are images of love, beauty, kindness, loyalty, creativity, compassion, joy; images of good and noble thinking, responsibility. As well as images of self-cognition, selfimprovement, which can guide children in this process of special instruction. Thus, the pedagogical technique should be modeled in such a way as to establish a consecutive "natural" order of forming "spiritual bodies" provided by especially tailored stages of educational process. Acquisition of ethical and 
moral knowledge becomes, at the same time, a process to develop the ability to "see" the surrounding world, yet not understood by the child, the objective reality of life through the prism of spiritual and moral values. The learner has the opportunity to ponder on the things perceived, not to repeat the words of others, even the most correct ones.

The specifics of the specialized pedagogical procedures that trigger the emotional intelligence is to harmonize - align with the perfect model of morality, coupled with resonance that involves the child both intellectually and emotionally. Harmonization, in contrast to a simple alignment with the moral ideal, awakes in the child the motivating enthusiasm to perform moral actions and deeds. The challenge is the manner, in which the teacher can harmonize the concept of the ideal moral action with the strategy of appropriate behavior to awake feelings of passion in the children. Practice shows that teachers who display emotional intelligence know that such harmonization implies more than mere provision of information on moral and ethical standards, characteristic of traditional pedagogy. Harmonization requires from the teacher to create a direct link with children's emotional centers. In this respect, the logic (algorithm) of modeling a lesson of spiritual and moral education foresees the realization of the moment, when this harmony becomes dominant, and the child feels a spark of joy, embraced by many members of the group (class), mobilizing their ability to act. The teacher's questions help the learners to direct themselves inward, engaging deeply in identifying the gap between their own interests and the interests of the others. It should be noted that the new strategy of pedagogical interaction, based on fostering the emotional intelligence, requires from the teachers a new culture of thinking, new attitudes and new behaviors, which they have to train during the activities.

\section{Conclusions}

The key to the shift in the educational processes from the main orientation towards the objective external reality to the formation of the child's inner world lies in choosing the correct intervention strategy. Traditional pedagogy teaches children to make choices in life, starting from the outside, from of the approval and acceptance of the others and not going into the depth, from the roots. Thus, it does not ensure the ability of learners to use the power of reason, to analyze all the possible consequences of their choices, especially when it comes to the spiritual and moral life.

We need to teach children to look inwards, or, as we know, human happiness comes from making our own choices, using our own judgment, based on our actions on our values and principles, rather than blindly accepting the choices, made for us by society. The fact that the child is born with the spirit of liberty, with an intellectual and emotional potential and with unflagging spiritual energy, will contribute, from the outset, to the efforts undertaken. All that the adults (parents, teachers) need to do is to be continually aware of effective ways that can influence their children and to do everything possible to apply them consistently and systematically. 


\section{Bibliography}

1. Abulihanova-Slaveanskaia. (1979). Iz naucinogo nasledia Sergheia Leonidovicia Rubinsteina (materiali iz arhiva ucionogo-psihologa). Voprosi Psihologii, 5, 140-150.

2. Anisimov, V.P. (2003). Art-pedagogika kak sistema psihologiceskogo sporovojdenia obrazovatelinogo protsesa. Vestnik $O G U, 147$.

3. Anisimov, V.P. (2014). K opredeleniu clicevogo poniatia art-pedagogikirebenok. Fundamentalinoe isledovania, 12-11, 2443-2445. Retrieved from http://www.fundamental-research.ru/ru/article/view?id=36711

4. Asmolov, A.G. (1989). Licinosti: psihologhicescaia strateghia vospitania. Novoe pedagogicescoe mislenie, 206-220.

5. Blasi, A. (1980). Bridging Moral Cognition and Moral Action: A Critical Review of the Literature. Psychological Bulletin, 88(1), 1-45.

6. Cucoș, C. (2008). Educaţia - raţionalistă sau umanistăa Retrieved from http: //www.constantincucos.ro/2008/09/396

7. Delors, J. (2000). Comoara lăuntrică. Raportul pentru UNESCO al Comisiei Internaţionale pentru educaţie în sec. XXI. Iaşi: Polirom.

8. Foca, E. (2015). Evolution of the concept ,art-pedagogy”. Review of Artistic Education, 9/10, 299-303. Retrieved from http://rae.arts.ro/index.php/archive/

9. Goleman, D., (2008). Inteligenţa emoţională. Bucureşti: Curtea Veche.

10. Iacobson, S.G. (1984). Psihologiceskie problemi eticeskogo razvitia detei. Pedagogika, 144, 84.

11. Methus, E. (2013). Invaţă-ţi copilul să gândească singur. Bucureşti: Aramis Print.

12. Şuşală, I. (2000). Estetica şi psihopedagogia artelor plastice şi designului. Bucureşti: Sigma.

13. Torralba, F. (2012). Inteligenţa spirituală. București: Curtea Veche.

14. Zolotariov, E. (2014). A vedea cu inima. Manual-suport pentru promovarea reperelor spiritual-morale în practica învăţământului modern. (Vols. 1-2). Chişinău: SA „Tipografia Reclama” 